\title{
Pengaruh Dana Pihak Ketiga, Loan To Deposit Ratio Dan Non Performing Loan Terhadap Jumlah Penyaluran Kredit Pada Bank Yang Terdaftar Di Bursa Efek Indonesia
}

\author{
Muhammad Firdaus' ${ }^{1}$ Edduar Hendri ${ }^{2}$, Ninin Non Ayu Salmah ${ }^{3}$ \\ ${ }^{1}$ Fakultas Ekonomi dan Bisnis Universitas PGRI Palembang, firdausprabu123@gmail.com \\ 2Fakultas Ekonomi dan Bisnis Univ. PGRI Palembang, hendriedduar71@univpgri-palembang.ac.id \\ ${ }^{3}$ Fakultas Ekonomi dan Bisnis Universitas PGRI Palembang, nininayusalmah@gmail.com
}

\begin{abstract}
This research aims to determine the influence of third party funds, Loan to Deposit Ratio and Non Performing Loan to the amount of credit distribution in banks listed on the Indonesia Stock Exchange.The Data observed in the form of annual financial statements period 2016-2018. Analysis of the data used is multiple linear regression by conducting classic assumption tests and then hypothesis tests with coefficient of determination test, $T$ test and $F$ Test. The results of the discussion can be noted that 1) Variable third party funds (DPK), Loan Deposit Ratio (LDR) and Non Performing Loan (NPL) significantly affect the amount of credit distribution in banks listed on the Indonesia Stock Exchange. 2) Variable of third party funds (DPK), significant effect on the amount of credit distribution in banks listed on the Indonesia Stock Exchange. 3) Deposit Ratio (LDR) significantly affects the number of credit distribution in banks listed on the Indonesia Stock Exchange. 4) The Non-Performing Loan (NPL) has no significant effect on the number of credit distribution in banks listed on the Indonesia Stock Exchange.
\end{abstract}

Keywords: Third party funds (DPK), Loan To Deposit Ratio (LDR), Non Performing Loan (NPL), Amount Of Credit Distribution

\begin{abstract}
ABSTRAK
Penelitian ini bertujuan untuk mengetahui pengaruh Dana Pihak Ketiga, Loan to Deposit Ratio dan Non Performing Loan terhadap jumlah penyaluran kredit pada bank yang terdaftar di bursa efek Indonesia. Data yang diamati berupa laporan keuangan tahunan periode 2016-2018. Analisis data yang digunakan yaitu regresi linear berganda dengan melakukan uji asumsi klasik lalu melakukan uji hipotesis dengan uji koefisien determinasi, uji T dan uji F. Hasil pembahasan dapat diketahui bahwa 1) Variabel Dana Pihak Ketiga (DPK), Loan Deposit Ratio (LDR) dan Non Performing Loan (NPL) berpengaruh signifikan terhadap jumlah penyaluran kredit pada bank yang terdaftar di Bursa Efek Indonesia. 2) variabel Dana Pihak Ketiga (DPK), berpengaruh signifikan terhadap jumlah penyaluran kredit pada bank yang terdaftar di bursa efek Indonesia. 3) Deposit Ratio (LDR) berpengaruh signifikan terhadap jumlah penyaluran kredit pada bank yang terdaftar di Bursa Efek Indonesia. 4) Non Performing Loan (NPL) berpengaruh tidak signifikan terhadap jumlah penyaluran kredit pada bank yang terdaftar di Bursa Efek Indonesia.
\end{abstract}

Kata Kunci: Dana Pihak Ketiga (DPK), Loan To Deposit Ratio (LDR), Non Performing Loan (NPL), Jumlah Penyaluran Kredit

\section{A. PENDAHULUAN}

Perbankan adalah sebuah lembaga yang sangat penting pada era sekarang karena semua orang dapat menggunakan jasa perbankan tanpa terkecuali, dari kalangan bawah sampai kalangan atas. Undang- undang RI No 10 tahun 1998 tanggal 10 November 1998 tentang Perbankan menyatakan bank merupakan badan usaha yang menghimpun dana dari masyarakat dalam bentuk simpanan dan menyalurkannya kepada masyarakat dalam bentuk kredit dan bentuk lainnya dalam rangka meningkatkan taraf hidup rakyat banyak. 
Krisis moneter yang terjadi pada tahun 1997, krisis finansial global pada tahun 2018 dan naiknya harga BBM pada tahun 2015 mempengaruhi kinerja keuangan sektor perbankan. Usaha penyaluran kredit yang dilakukan bank dan usaha pemerintah dalam memperbaiki kondisi perekonomian Indonesia tidak berjalan baik. Setiap tahunnya kredit yang disalurkan terus mengalami kenaikan, akan tetapi laju pertumbuhan tetap tidak stabil. Dalam menstabilkan perekonomian di Indonesia bank melakukan kebijakan kredit yang dapat dilihat dari beberapa variabel yaitu dana pihak ketiga (DPK), loan to deposit ratio (LDR), non performing loan (NPL).

Tabel Pertumbuhan Dana Pihak Ketiga, Loan To Deposit Ratio, Non Performing Loan dan Penyaluran Kredit Periode 2015-2018

\begin{tabular}{|c|c|c|c|c|}
\hline Tahun & $\begin{array}{c}\text { Dana Pihak } \\
\text { Ketiga }\end{array}$ & $\begin{array}{c}\text { Loan To } \\
\text { Deposit Ratio }\end{array}$ & $\begin{array}{c}\text { Non Performing } \\
\text { Loan }\end{array}$ & $\begin{array}{c}\text { Penyaluran } \\
\text { Kredit }\end{array}$ \\
\hline 2015 & $7,26 \%$ & $92,11 \%$ & $2,49 \%$ & $10,44 \%$ \\
\hline 2016 & $9,60 \%$ & $90,50 \%$ & $2,93 \%$ & $7,87 \%$ \\
\hline 2017 & $9,35 \%$ & $89,58 \%$ & $2,59 \%$ & $8,24 \%$ \\
\hline 2018 & $6,10 \%$ & $94,00 \%$ & $2,37 \%$ & $11,70 \%$ \\
\hline
\end{tabular}

Sumber : Otoritas Jasa Keuangan (OJK)

Berdasarkan data otoritas jasa keuangan diatas selama periode $2015-2018$ diketahui bahwa pertumbuhan Dana Pihak Ketiga (DPK) tertinggi sebesar 9,60\% terjadi pada tahun 2016 dan pertumbuhan Dana Pihak Ketiga (DPK) terendah sebesar 7,26\% terjadi pada tahun 2015. Selanjutnya pertumbuhan Loan To Deposit Ratio (LDR) tertinggi sebesar 94,00\% terjadi pada tahun 2018 dan pertumbuhan Loan To Deposit Ratio (LDR) terendah terjadi pada tahun 2017. Kemudian pertumbuhan Non Performing Loan (NPL) tertinggi sebesar 2,93\% terjadi pada tahun 2016 dan pertumbuhan Non Performing Loan (NPL) terendah sebesar 2,37\% terjadi pada tahun 2018. Pada tahun 2018 Dana Pihak Ketiga (DPK) mengalami penurunan yang membuat kondisi likuiditas dengan indikator Loan To Deposit Ratio (LDR) perbankan mengalami kenaikan dan kualitas aset perbankan dengan indikator kredit bermasalah (NPL) mengalami penurunan hal itu ternyata yang menyebabkan jumlah penyaluran kredit mengalami peningkatan.

\section{B. KAJIAN TEORI}

\section{1) Laporan Keuangan}

a. Pengertian Laporan Keuangan

Menurut PSAK (2018) laporan keuangan adalah informasi yang berhubungan dengan data keuangan dari perusahaan agar data keuangan dapat bermanfaat bagi pihak intern maupun ekstern. Menurut Diana (2018:1) laporan keuangan merupakan produk dari proses pelaporan keuangan yang diatur oleh standar akuntansi.

b. Tujuan Laporan Keuangan

Diana (2018:1) memaparkan alasan mengapa laporan keuangan itu diperlukan, yaitu:

1) Untuk melihat kondisi keuangan perusahaan. Hal ini sangat penting karena laporan keuangan akan mempermudah dalam melihat kondisi keuangan secara keseluruhan, sebab semua aktifitas perusahaan akan tercatat didalamnya.

2) Untuk mengetahui jumlah asset. Laporan keuangan akan sangat mempermudah memantau semua aset secara terperinci termasuk perubahan asset yang terjadi di dalam perusahaan dalam periode tertentu 
3) Untuk mengetahui jumlah liabilitas. Laporan keuangan akan mencatat semua jenis liabilitas termasuk tanggal jatuh tempo. Informasi ini sangat membantu dalam mengelolah liabilitas tersebut sehingga menjadi liabilitas yang produktif dan tidak bermasalah dikemudian hari.

4) Untuk mengetahui untung atau rugi. Dengan membaca laporan keuangan juga dapat mengetahui perkembangan usaha, sebab laporan keuangan meyajikan secara lengkap kondisi terakhir keuangan perusahaan.

5) Untuk mengetahui arah perusahaan. Laporan keuangan dapat menunjukkan kondisi yang sedang dialami perusahaan seperti, perkembangan, kemunduran, krisis, atau bahkan kebangkrutan yang memungkinkan akan dialami perusahaan.

\section{2) Dana Pihak Ketiga}

Kasmir (2016:59) mendefinisikandana pihak ketiga sebagai sumber dana terpenting bagi kegiatan operasional bank dan merupakan ukuran keberhasilan bank jika mampu membiayai operasionalnya dari sumber dana ini. Dana pihak ketiga merupakan sumber dana yang paling dominan dibanding sumber dana lainnya. Adapun sumberdana pihak ketiga yaitu:

a. Simpanan giro

Fahmi (2014:87) mendefinisikan giro sebagai sejumlah dana yang disimpan disuatu perbankan dan dna tersebut dapat ditarik berdasarkan permintaan seseorang dimana penarikannya itu biasanya dapat dilakukan dengan mengunakan cek atau bilyet giro. Dana giro ini dapat diambil kapan saja berdasarkan keinginan pihak yang bersangkutan.

b. Simpanan tabungan

Kasmir (2016:69) menjelaskan seperti halnya simpanan giro, simpanan tabungan juga mempunyai syarat syarat tertentu bagi pemegangnya dan persyaratan setiap bank berbeda satu sama lainnya.

c. Simpanan deposito

Kasmir (2016:74) menyatakan simpanan deposito merupakan simpanan yang mengandung unsur jangka waktu (jatuh tempo) lebih panjang dan tidak dapat ditarik setiap saat atau setiap hari.

\section{3) Analisis Rasio Keuangan}

a. Pengertian Analisis Rasio Keuangan

Analisis rasio keuangan adalah perbandingan angka-angka yang ada dalam laporan keuangan untuk mengetahui posisi keuangan suatu perusahaan serta menilai kinerja manajemen dalam suatu periode tertentu (Diana, 2018:51).

b. Tujuan Analisis Rasio Keuangan

Menurut Diana (2018:53) tujuan dari analisis rasio keuangan, yaitu:

> Untuk mengetahui posisi keuangan perusahaan dalam satu periode tertentu, baik harta, kewajiban, ekuitas, maupun hasil usaha yang telah dicapai untuk beberapa periode.

$>$ Untuk mengetahui kelemahan-kelemahan apa saja yang menjadi kekurangan perusahaan.

$>$ Untuk mengetahui kekuatan-kekuatan yang dimiliki.

$>$ Untuk mengetahui langkah-langkah perbaikan apa saja yang perlu dilakukan ke depan yang berkaitan dengan posisi keuangan perusahaan saat ini. 
- Untuk melakukan penilaian kinerja manajemen kedepan apakah perlu penyegaran atau tidak karena sudah dianggap berhasil atau gagal.

c. Macam - Macam Rasio Keuangan Bank

$>\quad$ Loan To Deposit Ratio (LDR)

Kasmir (2016:319) menjelaskan loan to deposit ratio merupakan rasio untuk mengukur komposisi jumlah kredit yang di berikan disbanding dengan jumlah dana masyarakat dan modal sendiri yang digunakan. Besarnya LDR menurut peraturan pemerintah maksimum adalah $110 \%$. Rasio ini dapat dijadikan patokan apakah bank masih dapat melakukan ekspansi terhadap pinjamannya atau harus membatasinya. Namun yang terjadi jika rasio LDR ini terlampau kecil yang artinya bahwa jumlah kredit yang disalurkan juga sedikit, hal ini akan berimbas pada bank yang akan kesulitan dalam menutup simpanan nasabahnya.

Rumus untuk mencari LDR sebagai berikut:

$$
\text { LDR }=\frac{\text { Kredit }}{\text { DPK }} \times 100 \%
$$

Non Performing Loan (NPL)

NPL diatur dalam Surat Keputusan Direktur Bank Indonesia Nomor 31/147/KEP/DIR tahun 1998. Dalam surat keputusan tersebutkredit digoLoankan menjadi lima, yaitu lancar, dalam perhatian khusus, kuranglancar, diragukan, dan macet. Tingkat kolektibilitas kredit yang dianggapbermasalah dan dapat mengganggu kegiatan operasional inilah yang disebut dengan kredit macet atau dikenal dengan Non Performing Loan (NPL). NPL diungkapkan melalui persentase dengan kriteria kurang lancar, diragukan, dan macet terhadap total kredit yang disalurkan. Bank Indonesia telah menetapkan ketentuan NPL sebesar 5\%. Apabila bank mampu menekan rasio NPL dibawah 5\%, maka potensi keuntungan yang akan diperoleh akan semakin besar, karena bank-bank akan menghemat uang yang diperlukan untuk membentuk cadangan kerugian kredit bermasalah.

\section{4) Kredit}

\section{a. Pengertian Kredit}

Undang-undang Perbankan No 10 Tahun 1998 menjelaskan kredit adalah penyediaan uang atau tagihan yang dapat dipersamakan dengan itu, berdasarkan persetujuan atau kesepakatan pinjam meminjam antar bank dengan pihak lain yang mewajibkan pihak peminjam melunasi hutangnya setelah jangka waktu tertentu dengan pemberian bunga.

b. Tujuan Kredit

Abdullah (2017:166) menyimpulkan bahwa tujuan utama pemberian kredit antara lain:

$>$ Mencari keuntungan yaitu bertujuan untuk memperoleh hasil dari pemberian kredit tersebut hasilnya terutama dalam bentuk bunga yang diterima oleh bank sebagai balas jasa dan biaya administrasi kredit yang dibebankan kepada nasabah.

> Membantu usaha nasabah yang memerlukan dana, baik dana investasi maupun dana untuk modal kerja.

Membantu pemerintah untuk peningkatan pembangunan di berbagai sektor. 


\section{5) Bank Umum}

Menurut Undang Undang Perbankan No. 10 Tahun 1998, bank adalah suatu badan usaha yang menghimpun dana dari masyarakat dalam bentuk simpanan dan menyalurkannya kepada masyarakat dalam bentuk kredit/atau bentuk-bentuk lainnya dalam rangka meningkatkan taraf hidup orang banyak.

\section{6) Bursa Efek Indonesia}

Hendro dan Rahardja (2014:349) menyimpulkan Bursa Efek Indonesia (BEI) adalah pihak yang menyediakan sarana untuk mempertemukan penawaran jual beli efek dengan tujuan memperdagangkan efek.BEI bersifat Self Regulatory Organization (SRO) agar mampu menciptakan perdagangan efek yang teratur, wajar, khususnya yang berkaitan dengan keanggotaan bursa, perdagangan, dan pencatatan efek.

\section{METODE PENELITIAN}

Bahri (2018:2) berpendapat bahwa metode penelitian adalah metode yang secara khusus mendeskripsikan tentang teknik pengumpulan data dan analisis data. Dalam penelitian ini metode penelitian yang penulis gunakan adalah metode kuantitatif. Penelitian ini dilakukan pada Bank yang terdaftar di Bursa Efek Indonesia (BEI).

Variabel independen atau variabel bebas, dalam penelitian ini adalah $X_{1}$ (dana pihak ketiga atau DPK), $\mathrm{X}_{2}$ (loan to deposit ratio atau LDR) dan $\mathrm{X}_{3}$ (non performing loan atau NPL). Variabel dependen atau variabel terikat dalam penelitian ini yaitu jumlah penyaluran kredit $(\mathrm{Y})$.

Populasi dalam penelitian ini adalah seluruh Bank yang menerbitkan laporan keuangannya pada Bursa Efek Indonesia dan terdapat 43 Bank. Dalam penelitian ini sempel diambil secara purposive sampling. Purposive sampling yaitu teknik pemilihan sampel dengan didasarkan pada kriteria-kriteria tertentu dengan tujuan untuk memberikan informasi yang maksimal (Sekaran dan Bougie, 2013:276). Adapun kriteria dalam penelitian ini di antaranya:

a. Perusahaan merupakan Bank Umum dan terdaftar di Bursa Efek Indonesia selama periode pengamatan.

b. Bank Umum tersebut mempublikasikan laporan keuangan selama periode tahun 2016 sampai dengan tahun 2018.

Dari kriteria diatas, Bank yang memenuhi kriteria dan menjadi sampel dalam penelitian ini berjumlah 28 Bank. Data dalam penelitian ini menggunakan data sekunder dengan teknik pengumpulan data menggunakan metode dokumentasi.

Teknik analisis data yang penulis gunakan dalam penelitian ini adalah statistik deskriptif. Lalu setelah itu melakukan uji asumsi klasik yang berupa uji normalitas, uji multikolinearitas, uji heterokedastisitas dan uji autokorelasi. Selanjutnya menentukan model regresi dengan menggunakan teknik analisis linear berganda. Sedangkan uji hipotesis menggunakan uji koefisien determinasi, uji T untuk mengetahui pengaruh persial dan uji $\mathrm{F}$ untuk mengetahui pengaruh simultan. Proses pengolahan data untuk penelitian ini menggunakan bantuan program software SPSS versi 22.0. 


\section{HASIL PENELITIAN}

1) Statistik Deskriptif

Tabel Deskriptif Statistik

Descriptive Statistics

\begin{tabular}{|l|l|l|l|l|}
\hline & $\mathbf{N}$ & Minimun & Maximum & Mean \\
\hline Jumlah penyaluran kredit & 84 & 2.65 & 3.39 & 2.9258 \\
Dana Pihak Ketiga & 84 & 2.65 & 3.41 & 2.9340 \\
Loan to deposit ratio & 84 & -2.94 & 2.40 & -.1544 \\
Non Performing loan & 84 & -3.00 & 2.79 & .9511 \\
Valid N (listwire) & 84 & \multicolumn{2}{|l}{} \\
\cline { 3 - 5 }
\end{tabular}

\section{Sumber: Hasil Olah Data SPSS Tahun 2020}

Berdasarkan tabel diatas variabel Jumlah Penyaluran Kredit memperoleh nilai minimum sebesar 2,65 dan nilai maksimum sebesar 3,39. Sedangkan nilai rataratanya diperoleh sebesar 2,9258. Variabel Dana Pihak Ketiga (DPK) memperoleh nilai minimum sebesar 2,65 dan nilai maksimum sebesar 3,41 . Sedangkan nilai rataratanya diperoleh sebesar 2,9340. Variabel Loan To Deposit Ratio (LDR) memperoleh nilai minimum sebesar -2,94dan nilai maksimum sebesar 2,40. Sedangkan nilai rata-ratanya diperoleh sebesar $-0,1544$. Variabel Non Performing Loan (NPL) memperoleh nilai minimum sebesar $-3,00$ dan nilai maksimum sebesar 2,76 . sedangkan nilai rata-ratanya diperoleh sebesar 0,9511 .

\section{2) Uji Asumsi Klasik}

\section{Uji Normalitas}

TABEL HASIL UJI NORMALITAS

\begin{tabular}{|l|l|l|l|}
\hline Variabel & Asymp. Sig. (2-tiled) & Standar uji normalitas & keterangan \\
\hline $\mathrm{X}_{1}, \mathrm{X}_{2}, \mathrm{X}_{3}, \mathrm{Y}$ & 0,054 & 0,05 & Normal \\
\hline
\end{tabular}

\section{Sumber: Hasil Olah Data SPSS Tahun 2020}

Berdasarkan hasil pengujian One-Sample Kolmogorov-Smirnov diperoleh nilai Asymp. Sig. (2-tailed) variabel independen sebesar 0,054 maka dapat ditarik kesimpulan jika data sampel telah memenuhi kriteria residual berdistribusi normal yang nilai signifikansinya diatas 0,05 .

\section{Uji Heterokedastisitas}

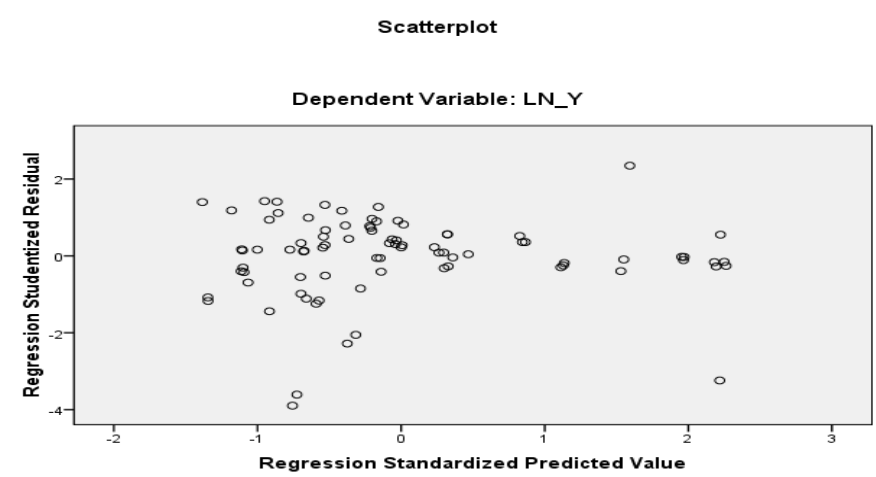

Gambar Hasil Uji Heterokedastisitas Sumber: Hasil Olah Data SPSS Tahun 2020 
Hasil grafik diatas menunjukkan titik-titik menyebar diatas dan dibawah angka 0 pada sumbu $Y$ dan tidak membentuk pola tertentu sehingga dapat ditarik kesimpulan bahwa model regresi baik karena tidak terjadi heterokedastisitas.

\section{Uji Multikolinearitas}

Tabel Hasil Uji Multikolinearitas

\begin{tabular}{|l|l|l|}
\hline \multicolumn{1}{|c|}{ Variabel } & \multicolumn{1}{c|}{ Tolerance } & VIF \\
\hline Dana Pihak Ketiga & .989 & 1.011 \\
\hline Loan to Deposit Ratio & .964 & 1.037 \\
\hline Non Performing Loan & .973 & 1.028 \\
\hline
\end{tabular}

Sumber : hasil olah data SPSS tahun 2020.

Tabel diatas menunjukkan nilai VIF pada Dana Pihak Ketiga (DPK) sebesar 1,011, VIF pada Loan To Deposit Ratio(LDR) sebesar 1,037, dan VIF pada Non Performing Loan (NPL) menunjukkan nilai sebesar 1,028. Nilai tolerance pada Dana Pihak Ketiga (DPK) sebesar 0,989, tolerance pada Loan To Deposit Ratio(LDR) sebesar 0,964 dan tolerance pada Non Performing Loan (NPL) menunjukkan nilai sebesar 0,973. Nilai-nilai pada variabel menunjukkan nilai VIF $<10$ dan nilai tolerance $>0,10$ sehinggadapat ditarik kesimpulan jika model regresi baik karena tidak terjadi gejala multikolinieritas.

\section{Uji Autokorelasi}

Tabel Hasil Uji Autokorelasi

\begin{tabular}{|l|c|l|}
\hline \multicolumn{1}{|c|}{ Variabel } & DW & \multicolumn{1}{c|}{ Keterangan } \\
\hline Dana Pihak Ketiga & 1.724 & Tidak terjadi Autokorelasi \\
\hline Loan to Deposite Ratio & 0.477 & Tidak terjadi Autokorelasi \\
\hline Non Performing Loan & 0.476 & Tidak terjadi Autokorelasi \\
\hline $\begin{array}{l}\text { Dana Pihak Ketiga, Loan to Deposit Ratio, } \\
\text { Non Performing Loan }\end{array}$ & 1.982 & Tidak terjadi Autokorelasi \\
\hline
\end{tabular}

Sumber: Hasil Olah Data SPSS Tahun 2020

Hasil dari pengujian Durbin Watson hitungmenunjukkan nilai DW Dana Pihak Ketiga (DPK) sebesar 1.724, nilai DW Loan to Deposite Ratio (LDR) sebesar 0.477, nilai DW Non Performing Loan (NPL) sebesar 0.476 dan Dana Pihak Ketiga (DPK), Loan to Deposite Ratio (LDR), Non Performing Loan (NPL). Nilai masing-masing terletak diantara -2 sampai +2 . Sehingga dapat disimpulkan bahwa model regresi ini tidak terjadi autokerelasi.

\section{Uji Regresi}

Tabel Hasil Uji Regresi

\begin{tabular}{|l|l|}
\hline \multicolumn{1}{|c|}{ Variabel } & \multicolumn{1}{c|}{ Nilai } \\
\hline$\alpha$ (konstanta) & -.027 \\
\hline Dana Pihak Ketiga & 1.008 \\
\hline Loan to Deposit Ratio & .039 \\
\hline Non Performing Loan & .000 \\
\hline
\end{tabular}

Sumber: Hasil Olah Data SPSS Tahun 2020 
Dilihat dari tabel diatas, diperoleh suatu model persamaan regresi linier berganda sebagai berikut:

$$
Y=-0,027+1,008 X_{1}+0,039 X_{2}+0,000 X_{3}
$$

Berdasarkan persamaan regresi diproleh nilai konstanta sebesar $-0,027$. Artinya tanpa pengaruh variabel DPK LDR dan NPL maka jumlah penyaluran kredit sebesar $-0,027$ satuan. Variabel DPK memiliki nilai koefisien yang positif sebesar 1,008 artinya jika DPK naik sebanyak 1 satuan, maka jumlah penyaluran kredit akan meningkat sebesar 1,008 satuan dan sebaliknya jika DPK turun sebanyak 1 satuan, maka jumlah penyaluran kredit akan menurun sebesar 1,008 satuan. Variabel LDR memiliki nilai koefisien yang positif sebesar 0,039 artinya jika LDR naik sebanyak 1 satuan maka jumlah penyaluran kredit akan meningkat sebesar 0,039 satuan dan sebaliknya jika LDR naik sebanyak 1 satuan, maka jumlah penyaluran kredit akan meningkat sebesar 0,039 satuan. Variabel NPL memiliki nilai koefisien yang positif sebesar 0,000 artinya jika NPL naik atau turun sebesar 1 satuan maka jumlah penyaluran kredit tidak berpengaruh terpengaruh.

\section{Koefisien Determinasi}

Tabel Hasil Uji Koefisien Determinasi

\begin{tabular}{|l|l|l|l|l|l|}
\hline Variabel & $\mathbf{R}$ & $\mathbf{R}$ Square & $\begin{array}{l}\text { Adjusted } \mathbf{R} \\
\text { Square }\end{array}$ & $\begin{array}{l}\text { Std. Error of } \\
\text { the estimate }\end{array}$ & $\begin{array}{l}\text { Durbin } \\
\text { Watson }\end{array}$ \\
\hline $\begin{array}{l}\text { X1-Lnx1 } \\
\text { X2-Lnx2 } \\
\text { X2-Lnx3 }\end{array}$ & .303 & .092 & .081 & .00307142 & 1.982 \\
\hline
\end{tabular}

Sumber: Hasil Olah Data SPSS Tahun 2020

Berdasarkan hasil pengujian diatas, diperoleh hasil Adjusted $R$. Square sebesar 0,081 sehingga variabel bebas DPK, LDR dan NPL dapat menjelaskan variabel terikat Jumlah Penyaluran Kredit sebesar 8,1\%. Sisanya 91,9\% dijelaskan oleh faktor lain yang tidak dimasukkan dalam model regresi diantaranya net interest margin dan capital adequacy ratio.

\section{Uji Hipotesis}

\section{$>\quad$ Uji F}

Tabel Hasil Uji Statistik F

\begin{tabular}{|c|c|c|c|}
\hline Variabel & Signifikan & $\alpha=0.05$ & Keterangan \\
\hline $\begin{array}{l}\text { Dana Pihak Ketiga, } \\
\text { Loan to Deposit } \\
\text { Ratio dan Non } \\
\text { Performing Loan }\end{array}$ & 0.005 & 0.05 & Signifikan \\
\hline
\end{tabular}

Sumber: Hasil Olah Data SPSS Tahun 2020

Berdasarkan tabel diatas diperoleh nilai signifikan sebesar 0,005 lebih kecil dari 0,05 . Sedangkan berdasarkan perbandingan, $F_{\text {hitung }}$ memperoleh nilai 8,210 lebih besar dari pada $\mathrm{F}_{\text {tabel }}$ sebesar 2,72, maka dapat ditarik kesimpulan $\mathrm{H}_{1}$ diterimayang berarti secara simultan DPK, LDR, dan NPL berpengaruh signifikan terhadap Jumlah Penyaluran Kredit. 
Tabel Hasil Uji Statistik T

\begin{tabular}{|l|l|l|l|}
\hline \multicolumn{1}{|c|}{ Variabel } & Signifikan & \multicolumn{1}{c|}{$\boldsymbol{\alpha = 0 . 0 5}$} & \multicolumn{1}{c|}{ Keterangan } \\
\hline Dana Pihak Ketiga & .000 & 0.05 & Signifikan \\
\hline Loan to Deposit Ratio & .000 & 0.05 & Signifikan \\
\hline Non Performing Loan & .376 & 0,05 & Tidak Signifikan \\
\hline
\end{tabular}

Sumber: Hasil Olah Data SPSS Tahun 2020

Berdasarkan tabel diatas, uji t dengan variabel bebas DPK diperoleh nilai Sig. $t$ sebesar 0,000 atau lebih kecil dari 0,05. Sedangkan berdasarkan perbandingan, thitung memperoleh nilai sebesar 574,266 lebih besar dari pada tabel sebesar 1,992. Sesuai dengan kriteria penerimaan hipotesis maka dapat ditarik kesimpulan $\mathrm{H}_{2}$ diterima yang berartisecara parsial, DPK berpengaruh signifikan terhadap Jumlah Penyaluran Kredit.

Uji parsial dengan variabel bebas LDR diperoleh nilai Sig. t sebesar 0,000 atau lebih kecil dari 0,05. Sedangkan berdasarkan perbandingan, thitung memperoleh nilai 48,409 lebih besar dari pada $t_{\text {tabel }}$ sebesar 1,992. Sesuai dengan kriteria penerimaan hipotesis maka dapat ditarik kesimpulan $\mathrm{H}_{3}$ diterima yang berarti secara pasrsial LDR berpengaruh signifikan terhadap Jumlah Penyaluran Kredit.

Uji parsial dengan variabel bebas NPL diperoleh nilai Sig. t sebesar 0,376 atau lebih besar dari 0,05. Sedangkan berdasarkan perbandingan, thitung memperoleh nilai 0.890 lebih kecil dari pada $t_{\text {tabel }}$ sebesar 1,992. Sesuai dengan kriteria penerimaan hipotesis maka dapat ditarik kesimpulan $\mathrm{H}_{4}$ ditolak yang berarti secara parsial NPL tidak berpengaruh signifikan terhadap Jumlah Penyaluran Kredit.

\section{E. PEMBAHASAN}

1. Pengaruh DPK, LDR dan NPL terhadap jumlah penyaluran kredit pada bank yang terdaftar di Bursa Efek Indonesia.

Hasil pengujian hipotesis diperoleh nilai Sig. F sebesar 0,005 atau lebih kecil dari 0,05 . Sedangkan berdasarkan perbandingan, $F_{\text {hitung }}$ memperoleh nilai 8,210 lebih besar dari pada $F_{\text {tabel }}$ sebesar 3,56 , Sesuai dengankriteria penerimaan hipotesis maka dapat ditarik kesimpulan $\mathrm{H}_{1}$ diterima, yang berartisecara simultan DPK, LDR, dan NPL berpengaruh signifikan terhadap Jumlah Penyaluran Kreditpada bank yang terdaftar di Bursa Efek Indonesia.

Hasil penelitian ini senada dengan penelitian yang dilakukan oleh Triasdini (2010:6), Amelia dan Murtiasih (2015:66), Octavia (2016:33) Mulyati (2017:12) dan Rasasti (2017) yang menyatakan bahwa secara simultan, variabel Dana Pihak Ketiga (DPK), Loan Deposit Ratio (LDR) dan Non Performing Loan (NPL) berpengaruh signifikan terhadap jumlah penyaluran kredit.

\section{Pengaruh dana pihak ketiga (DPK) terhadap jumlah penyaluran kredit} pada bank yang terdaftar di Bursa Efek Indonesia.

Hasil pengujian hipotesis diperoleh nilai Sig. t sebesar 0,000atau lebih kecil dari 0,05 . Sedangkan berdasarkan perbandingan, thitung memperoleh nilai sebesar 574,266 lebih besar dari pada tabel sebesar 1,992. Sesuai dengan kriteria penerimaan hipotesis maka dapat ditarik kesimpulan $\mathrm{H}_{2}$ diterima, yang berartisecara parsial DPK berpengaruh signifikan terhadap Jumlah Penyaluran Kredit pada bank yang terdaftar di Bursa Efek Indonesia. 
Hasil penelitian ini senada dengan penelitian yang dilakukan oleh Amelia dan Murtiasih (2015:66), Octavia (2016:3) dan Mulyati (2017:12) yang menyatakan bahwa variabel DPK berpengaruh positif dan signifikan terhadap Penyaluran Kredit. Sedangkan hasil yang berbeda ditunjukkan oleh Febrianto dan Dul Muid (2013:1) yang menyatakan bahwa variabel DPK tidak berpengaruh secara signifikan terhadapJumlah Penyaluran Kredit.

\section{Pengaruh loan to deposit ratio (LDR) terhadap jumlah penyaluran kredit pada bank yang terdaftar di Bursa Efek Indonesia.}

Hasil pengujian hipotesis diperoleh nilai Sig. t sebesar 0,000 atau lebih kecil dari 0,05 . Sedangkan berdasarkan perbandingan, thitung memperoleh nilai 48,409 lebih besar dari pada tabel sebesar 1,992.Sesuai dengan kriteria penerimaan hipotesis maka dapat ditarik kesimpulan $\mathrm{H}_{3}$ diterima, yang berartisecara parsial LDR berpengaruh signifikan terhadap Jumlah Penyaluran Kredit pada bank yang terdaftar di Bursa Efek Indonesia.

Hasil penelitian ini senada dengan penelitian yang dilakukan oleh Febrianto dan Dul Muid (2013:1), Amelia dan Murtiasih (2015:66), Octavia (2016:3) dan Mulyati (2017:12) yang menyatakan bahwa LDR berpengaruh secara signifikan dan positif terhadap Jumlah Penyaluran Kredit.

\section{Pengaruh non performing loan (NPL) terhadap jumlah penyaluran kredit pada bank yang terdaftar di Bursa Efek Indonesia.}

Hasil pengujian hipotesis diperoleh nilai Sig. t sebesar 0,376 atau lebih besar dari 0,05 . Sedangkan berdasarkan perbandingan, thitung memperoleh nilai 0.890 lebih kecil dari pada tabel sebesar 1,992.Sesuai dengan kriteria penerimaan hipotesis maka dapat ditarik kesimpulan $\mathrm{H}_{4}$ ditolak, yang berarti secara parsial NPL tidak berpengaruh signifikan terhadap Jumlah Penyaluran Kredit pada bank yang terdaftar di Bursa Efek Indonesia.

Hasil penelitian ini senada dengan penelitian yang dilakukan oleh Febrianto dan Dul Muid (2013:1), Octavia (2016:3) dan Mulyati (2017:12) yang menyatakan bahwa NPL tidak berpengaruh secara signifikan dan negatif terhadap Jumlah Penyaluran Kredit. Sedangkan hasil yang berbeda ditunjukkan oleh Triasdini (2010:6) yang menyatakan bahwa NPL berpengaruh signifikan terhadap jumlah penyaluran kredit.

\section{F. KESIMPULAN DAN SARAN}

1) Kesimpulan

Setelah dilakukan penelitian dan pengujian maka kesimpulan pada penelitian ini adalah bahwa :

a. Secara simultan, Dana Pihak Ketiga (DPK), Loan Deposit Ratio (LDR) dan Non Performing Loan (NPL) berpengaruh signifikan terhadap jumlah penyaluran kredit pada bank yang terdaftar di Bursa Efek Indonesia. Hal ini dapat dilihat dari hasil nilai signifikan sebesar 0,005 lebih kecil dari 0,05. Sedangkan berdasarkan perbandingan, $F_{\text {hitung }}$ memperoleh nilai 8,210 lebih besar dari pada $F_{\text {tabel }}$ sebesar 2,72.

b. Secara parsial, Dana Pihak Ketiga (DPK) berpengaruh signifikan terhadap jumlah penyaluran kredit pada bank yang terdaftar di bursa efek Indonesia. Hal ini dapat dilihat dari hasil nilai signifikan sebesar 0,000 lebih kecil dari nilai signifikansi 0,05. Sedangkan berdasarkan perbandingan, thitung memperoleh nilai sebesar 574,266 lebih besar dari pada tabel sebesar 1,992. 
c. Secara parsial, Loan Deposit Ratio (LDR) berpengaruh signifikan terhadap jumlah penyaluran kredit pada bank yang terdaftar di Bursa Efek Indonesia. Hal ini dapat dilihat dari hasil nilai signifikan sebesar 0,000 lebih kecil dari nilai signifikansi 0,05 . Sedangkan berdasarkan perbandingan, thitung memperoleh nilai 48,409 lebih besar dari pada tabel sebesar 1,992.

d. Secara parsial, Non Performing Loan (NPL) tidak berpengaruh signifikan terhadap jumlah penyaluran kredit pada bank yang terdaftar di Bursa Efek Indonesia. Hal ini dapat dilihat dari hasil nilai signifikan sebesar 0,376 atau lebih besar dari nilai signifikansi 0,05. Sedangkan berdasarkan perbandingan, thitung memperoleh nilai 0.890 lebih kecil dari pada tabel sebesar 1,992.

\section{2) Saran}

Dari hasil penelitian yang telah dilakukan dan berdasarkan pada simpulan di atas, maka saran yang bisa disampaikan diantarannya :

a. Bagi penguna laporan keuangan khususnya investor, masyarakat dan pihak internal bank yang terdaftar di bursa efek Indonesia hendaknya lebih memperhatikan lagi Dana Pihak Ketiga dan rasio-rasio keuangan perbankan terutama rasio LDR dalam mengambil keputusan.

b. Bagi penelitian selanjutnya hendaknya untuk menambahkan rasio keuangan bank lainnya sebagai variabel independen karena kemungkinan rasio keuangan yang tidak dimasukkan dalam penelitian ini berpengaruh terhadap jumlah penyaluran kredit.

\section{DAFTAR PUSTAKA}

Abdullah, Thamrin. 2017. Bank dan Lembaga Keuangan Edisi 1 Cetakan 4. Jakarta: PT RajaGrafindo Persada.

Amelia, Kharisma Citra dan Sri Murtiasih. 2017. Analisis Pengaruh DPK, LDR, NPL dan CAR Terhadap Jumlah Penyaluran Kredit Pada PT Bank Indonesia Periode 2005-2014. Vol:22 No. 1. (Jurnal)

Artikel Pendidikan. 2019. Pengertian Laporan Keuangan Menurut PSAK 2018 (Online)

Bahri, Syaiful. 2018. Metodologi Penelitian Bisnis Lengkap Dengan Teknik Pengelolahan Data SPSS.Yogyakarta: ANDI.

Diana, Shinta Rahma. 2018. Analisis Laporan Keuangan dan Aplikasi. Bogor: INMEDIA.

Fahmi, Irham. 2014. Bank dan Lembaga Keuangan Lainnya Teori dan Aplikasi. Bandung: Alfabeta.

Febriyanto, Dwi Fajar. 2013. Analisis pengaruh dana pihak ketiga, LDR, NPL, CAR, ROA, dan BOPO terhadap Jumlah Penyaluran Kredit. Vol: 2 No. 4 Hal. 1-11. (Jurnal) 
Galih, Tito Aditya. 2011. Pengaruh DPK, CAR, NPL, ROA dan LDR Terhadap Jumlah Penyaluran Kredit Pada Bank Indonesia. (Jurnal)

Hendro, Tri dan Conny Tjandra Rahardja. 2014. Bank \& Institut Keuangan Non Bank Di Indonesia cetakan 1. Yogyakarta: UPP STIM YKPN.

Kasmir. 2016. Bank dan Lembaga Keuangan Lainnya Edisi Revisi 2014 Cetakan ke17.Jakarta: PT RajaGrafindo Persada.

Mulyati, Suci. 2017. Pengaruh DPK, NPL dan LDR Terhadap Penyaluran Kredit Periode 2013-2016. (Jurnal)

Oktavia, Anggi. 2016. Analisis Pengaruh DPK, LDR, CAR, ROA, NPL dan Faktor Eksternal Terhadap Jumlah Penyaluran Kredit (Studi Pada Bank Umum Yang Terdaftar Di Bursa Efek Indonesia Periode 2010-2014). (Jurnal)

Pauzi, Agus. 2011. Analisis Dan Pihak Ketiga NPL, CAR dan LDR Terhadap ROA Serta Implikasinya Terhadap Penyaliran Kredit Pada Bank Persero. (Jurnal)

Triasdini, Himaniar.2010. Pengaruh CAR, NPL dan ROA Terhadap Penyaluran Kredit (Studi Pada Bank Umum yang Terdaftar di Bursa Efek Indonesia 20042009). (Jurnal)

Yuwono, Febri Amithya. 2012. Analisis Pengaruh Dana Pihak Ketiga, Loan To Deposit Ratio, Capital Adequacy Ratio, Non Performing Loan, Return On Assets, dan Sertifikat Bank Indonesia Terhadap Jumlah Penyaluran Kredit.(Jurnal) 